\title{
Incertidumbre y expectativas para el nacimiento de una nueva revista
}

\author{
On launching a new academic journal \\ Incerteza e expectativas ao lançar uma nova revista
}

\begin{abstract}
Resumen
Este texto presenta el primer número de la revista académica Árboles y Rizomas, describiendo sus objetivos, foco y alcances. Definimos y discutimos acerca del contexto de producción y recepción en el ecosistema de la comunicación científica en humanidades señalando incertidumbres, expectativas y la necesidad de colaboración en los procesos editoriales. Se presenta el nombre de la revista como anclaje conceptual que oriente su destino y, a partir de la metáfora de un nuevo barco que parte, se enuncia el acto performativo de su lanzamiento.
\end{abstract}

Palabras clave: nueva revista académica, edición en humanidades, lanzamiento de revista.

\begin{abstract}
This text introduces the first issue of the journal Árboles y Rizomas by describing its objectives, focus and scope. We define and discuss about the context of production and reception in the ecosystem of scientific communication in the humanities, mentioning uncertainties, expectations and the need for collaboration in the editing processes. The name of the journal is presented as the conceptual anchoring that guides its route and using the metaphor of a new boat that sets sails, the performative act for its launching is uttered.
\end{abstract}

Keywords: new academic journal, editing in humanities, journal launching.

\section{Resumo}

Este texto apresenta a primeira edição da revista acadêmica Árboles y Rizomas, descrevendo seus objetivos, foco e escopo. Definimos e discutimos o contexto de produção e recepção no ecossistema da comunicação científica nas ciências humanas, apontando incertezas, expectativas e a necessidade de colaboração nos processos editoriais. O nome da revista é apresentado como uma âncora conceitual que orienta seu destino e, a partir da metáfora de um novo navio que inicia, o ato performativo de seu lançamento é enunciado.

Palavras-chave: novo periódico acadêmico, edição de humanidades, lançamento de revista.

Con una sensación de incertidumbre pero también placentera y con muchas expectativas, presentamos a la comunidad académica y a las comunidades lectoras especializadas la revista Árboles y Rizomas: Revista de Estudios Lingüísticos y Literarios. Árboles y Rizomas es una revista académica de arbitraje doble ciego que ofrece un espacio de diálogo académico en torno a investigaciones en el área de los estudios literarios y lingüísticos, convocando a todos aquellos que tengan al lenguaje como centro de sus preocupaciones, ya sea en sus expresiones poéticas, en su concreción como lengua en uso en discurso y géneros discursivos varios. Su objetivo es estimular, divulgar y contribuir al desarrollo de los estudios literarios y lingüísticos y de sus 


\section{Miguel Farías}

múltiples zonas de convergencia. Como ejemplos, pero no restringidos a estos temas, se aceptan trabajos: a) en estudios lingüísticos que aborden los distintos niveles de la lengua: fonológicos, sintácticos, semánticos, pragmáticos, discursivos, ideológicos; b) semiótica; c) lengua, sociedad y cultura; d) lengua y cognición; e) lengua e ideología; f) lengua y otros modos semióticos; g) lingüística queer; h) etnolinguiística; i) lengua y educación. En estudios literarios: a) teoría literaria; b) literatura de los márgenes (el Sur, los bordes); c) estudios de géneros (crítica literaria feminista, estudios queer, etc.); d) estudios postcoloniales (subalternidad); e) crítica literaria latinoamericana.

El gesto de niñez de lanzar un barco de papel al agua puede emular, con las debidas diferencias, el momento de finalmente hacer visible un proyecto de publicación que nace al interior del Departamento de Lingüística y Literatura de la Universidad de Santiago, pero que, como su nombre lo adelanta, se nutre y conecta con los apoyos (tácitos y explícitos) de muchos colegas en diferentes paralelos y meridianos en este mundo globalizado y glocalizado.

Es un momento placentero por los contactos que se establecen o renuevan y por la posibilidad de ofrecer un espacio de diálogo en torno a temas que rondan nuestros pensamientos sobre el impacto de la globalización, las migraciones, el terrorismo y las tecnologías de la información en las tradicionales preocupaciones de las humanidades. Así mismo, en relación a otros temas que se han instalado en los últimos tiempos como los problemas de género, los exilios, el tecno neoliberalismo, la sobrevivencia de las comunidades indígenas y otros que desafían el amplio espectro de la lengua y la literatura. Esperamos que en los intercambios de nuestros trabajos seamos capaces de encontrar referentes y reafirmaciones para enfrentar la incertidumbre que los vertiginosos cambios en el paisaje socio semiótico nos interpelan a diario. Incertidumbre también, en un sentido más burocrático, por el marco de tensiones del mundo de las publicaciones académicas que se debaten y, a veces, zozobran en el mar de las indexaciones y otros desafíos impuestos por la métrica de la productividad. Sin embargo, esta incertidumbre debiera disiparse en la búsqueda de la optimización de los procesos editoriales que estamos conociendo y donde editores y autores trabajen mancomunadamente en pos de la valoración del conocimiento generado en nuestras comunidades discursivas (Farías, 2018).

Las expectativas son favorecer, en la medida de lo posible, un proceso de acompañamiento en la difusión de investigaciones en los amplios campos de los estudios literarios y lingüísticos en el contexto latinoamericano. Tenemos que contar también con expectativas corporativas que esperan una indización de esta revista en los registros métricos de productividad académica.

A partir del nombre, hablamos de estudios literarios y lingüísticos más que de literatura y lingüística (que serían los referentes disciplinarios canónicos) con el fin de convocar a todos quienes tengan como centro de sus preocupaciones el lenguaje, sea en sus expresiones poéticas y literarias y/o en su concreción como lengua en uso, en discursos y géneros discursivos varios. Por otra parte, el concepto de estudios nos abre las posibilidades tanto a los alcances semióticos que presenta la comunicación humana con el vertiginoso y apabullante ingreso de las imágenes, de la lectura en pantalla y de la profundidad inmensa y extravagante de los hipervínculos como a la valoración del ensayo y otros géneros como medios de expresión en la humanidades (Valdés, 2017).

Vemos un horizonte posible siempre que contemos con la generosa colaboración tanto de autores, personal de apoyo, así como de nuestros evaluadores. La edición de una revista académica que persigue estándares de calidad es un trabajo colosal y es de esperar que este barco que se lanza en su primer número, llegue a muchos puertos y permita internacionalizar el trabajo 


\section{Miguel Farías}

académico en el campo de las humanidades que se gesta en la Universidad de Santiago de Chile y, al mismo tiempo, difundir aquel de colegas de otras latitudes. En la cotidianidad de las bambalinas editoriales de esta revista, un agradecimiento gigante al apoyo constante de Diana Pasmanik y Lorena Garrido, Coordinadora General y Asistente de Edición, sin quienes este trabajo no hubiese sido posible. Por supuesto, agradecer a todos y todas las evaluadoras que enriquecieron con sus comentarios los trabajos que se publican.

Hemos tomado el concepto de árboles y rizomas de Deleuze y Guattari (1987) porque representa metafóricamente la dinámica epistemológica y metodológica que caracteriza las principales orientaciones en la investigación de los estudios literarios y lingüísticos: atender, por una parte, a patrones recurrentes y recursivos que nos permitan hacer entradas arbóreas en los textos y discursos y, por otra parte, poner atención a la polifonía, las discontinuidades y vasos comunicantes distantes y discontinuos en la rizomática comunicación textual humana. El nombre no es solo un anclaje epistemológico diverso sino que también refiere a la necesidad de fortalecer las redes académicas del Sur con prácticas rizomáticas descolonizadoras y de colaboración. En consecuencia, la revista se publica en tres lenguas; inglés, como lengua internacional de las comunicaciones, español y portugués, como las lenguas de comunicación del $94 \%$ de los habitantes de América Latina (Moreno y Otero, 2016).

Este primer número comienza con el trabajo de Teun Van Dijk sobre algunos conceptos necesarios para abordar la relación entre discurso y conocimiento que integre la dimensión sociocognitiva en el procesamiento del discurso. En esta versión del trabajo el concepto de conocimiento de terreno común se ha denominado conocimiento cultural, en concordancia con desarrollos posteriores de la tipología de conocimientos. Se trata de un trabajo pionero que posteriormente se plasmará en trabajos (como Van Dijk, 2014) que tienen como objetivo buscar una definición de conocimiento como creencia consensuada en comunidades epistémicas y como asignación de conocimiento en contextos discursivos.

El segundo artículo de Carmen Tisnado aborda, a partir de las similitudes en los títulos, las representaciones de España en la obra del autor peruano Iwasaki en su diálogo con el texto canónico de Vallejo España aparta de mí este cáliz. La autora concluye que a pesar de que ambas voces representan una España globalizada, la de Vallejo dialoga con otros países, fuera de España, en tanto Iwasaki dialoga con la diversidad cultural interna que aporta la globalización.

En el tercer artículo, Claudio Araya nos ofrece una arista de su trabajo doctoral sobre las representaciones de la comunidad gay en dos medios de prensa chilena en línea, o ciberprensa, a partir de la discusión de iniciativas políticas como el Acuerdo de Unión Civil y la adopción homoparental. El corpus analizado por medio de la teoría de la valoración y en el marco de los estudios críticos del discurso muestra que, a pesar de tales iniciativas, subyace una ideología conservadora apoyada en una heteronorma que regula la sexualidad y la afectividad.

En el cuarto artículo escrito en inglés, Language policies in Brazil and the epistemology underlying the selection of foreign language textbooks, sus autoras Gicele Vieira y Kyria Finardi, enriqueciendo su línea de investigación en la enseñanza del inglés e internacionalización, vuelcan su mirada al análisis de las orientaciones en la selección de textos para la enseñanza y aprendizaje del inglés y su relación con las políticas linguiísticas en Brasil. A partir de sus resultados alertan sobre la necesidad de ampliar la perspectiva de la enseñanza del inglés para una ciudadanía globalizada.

En Incidental vocabulary acquisition from documentary viewing: A study on the role of captions, Marion Durbahn nos muestra el resultado de su investigación sobre la adquisición del vocabulario incidental, para lo cual observó los efectos de los subtítulos en inglés en la 
visualización de un documental científico por parte de hispanohablantes. Los resultados en términos de adquisición de vocabulario en la L2 y la recuperación de las formas ortográficas es un aporte a los estudios en lingüística aplicada y, en particular, en lo relativo a los procesos involucrados en el aprendizaje de segundas lenguas.

En el penúltimo artículo que se presenta en este primer número, Jaime Amaro analiza Formas de volver a casa del autor chileno Alejandro Zambra, a partir de la poética del fragmento, teoría que permite recoger en la fragmentariedad de las obras escritas en y sobre la dictadura, una estructura acorde a la expresión de una realidad factual y escritural quebrada.

En el último trabajo, Marcos Cárdenas nos ofrece un artículo sobre la predicación que convoca las dimensiones sintácticas y semánticas de la lengua. Se enfoca en la predicación secundaria y el debate en cuanto a si es una cláusula mínima o tiene categoría funcional. La discusión se proyecta a los alcances neurolingüísticos de las representaciones sintácticas en modelos neuronales de la lengua.

Esta primera entrega de Árboles y Rizomas concluye con dos reseñas, una sobre un último libro del lingüista Eugenio Coseriu acerca de tendencias y escuelas en los estudios semánticos, escrita por Carlos Echeverría, y otra, una doble reseña escrita por Sebastián Reyes sobre dos novelas que abordan temas de frontera e inmigración.

Con esta valiosa carga que incluye los trabajos que han llegado a un primer llamado a colaborar en este proyecto editorial, esperamos que este barco llegue a buen puerto y que toque muchos otros puertos en el futuro.

\section{On launching a new academic journal}

With a mixture of pleasure, uncertainty and anticipation, we present the journal Árboles $y$ Rizomas: Revista de Estudios Lingüísticos y Literarios to the academic community and specialized readers. Árboles y Rizomas is an academic, open access, peer reviewed journal that offers a space for discussion regarding research in literature and linguistics studies. Manuscripts having a focus on language either as poetic expression and/or as language-in-use in various genres are welcome. The journal's objectives are to encourage, disseminate and contribute to the advancement of studies in literature and linguistics and their varied convergence zones. Examples of possible thematic areas in linguistics, but not restricted to them, are: a) papers that deal with different linguistic levels of analysis: phonological, grammatical, pragmatic, discoursal, ideological; b) semiotics; c) language, society and culture; d) language and cognition; e) language and ideology; f) language and other semiotic modes; g) queer linguistics; h) ethnolinguistics; i) language and education. In literary studies: a) literary theory; b) border literatures (the South, the borders); c) gender studies (feminist literary criticism, queer studies, etc.); d) postcolonial studies (the subaltern); e) Latin-American literary criticism.

This moment of finally realizing a publishing project begun in the Department of Linguistics and Literature in the Universidad de Santiago de Chile in some ways recalls that gesture, dating from childhood, of launching the first of a fleet of paper boats across the water. The growth of this project, however, springs forth and connects through the collaborations (tacit and explicit) of colleagues at many different parallels and meridians in this globalized and glocalized world.

Pleasure, both in the contacts established and renewed, and in the prospect of offering a space to engage in dialogue about recurring topics such as the impact of globalization, migrations, terrorism and technologies, all areas located, traditionally, within the domain of 


\section{Miguel Farías}

humanistic study. In exchanging and sharing our work, we hope to find references and reassurances with which to face down the daily uncertainties brought about by the vertiginous changes in the socio semiotic intellectual landscape. One such uncertainty would be bureaucratic, caught up and sometimes pulled far off course by the treacherous currents of index rates and other challenges imposed by productivity metrics. That uncertainty should dissipate, however, as we seek both to optimize our editorial processes and, as editors and authors, to work hand-inhand, valuing the knowledge that is produced in our discourse communities (Farías, 2018).

We hope that our editorial process will foment the publication of research across the full range of studies in literature and linguistics in the Latin-American context. Here, we should also mention the institutional expectations, which are that this journal will eventually be indexed in the metrics of academic productivity.

The title of the journal concerns "studies in literature and linguistics" as we intend to invite everyone for whom language is a central endeavor, be it as poetic expressions and/or as language in use, in discourses and genres of a variegated nature. The concept of "studies" opens up multiple possibilities for engagement across the full scope of semiotics, as human communication moves through and into a dizzying onslaught of images for reading on screen; within the immense and potentially deranging depth of hyperlinks, the essay continues to hold profound value as a means of expression in the humanities (Valdés, 2017).

We glimpse a feasible horizon insofar as we can count on the generous collaboration from our hardy crew of authors, support staff and evaluators who do the massive labor of editing an academic journal that upholds quality standards. We hope that the launch of the first issue of this boat brings it to many ports, internationalizing the academic work in the humanities developed in the Universidad de Santiago de Chile. At the same time, we expect to disseminate work by colleagues in other latitudes. As for those whose editorial labor took place behind the scenes, enormous gratitude goes to the constant support of Diana Pasmanik and Lorena Garrido, General Coordinator and Assistant to the Editor, without whose diligent work this publication would not have been possible. Of course, our appreciation to all evaluators whose valuable comments helped strengthen the papers published here.

We have taken the concept of "trees and rhizomes" from Deleuze \& Guattari (1987), whose metaphor represents the epistemology on which the main research orientations in linguistics and literature are founded. On the one hand, there is a focus on the recurring and recursive patterns involved in an arboreal take on texts and discourses. On the other hand, there is attention to polyphony, to discontinuities and to the communicating vessels through which human textual communication extends rhizomatically. This name at once refers to epistemological anchoring and to the need to reinforce, by way of decolonizing and collaborative rhizomatic nodes and practices, the academic networks in the South. Consequently, the journal is published in three languages: English, as an international language alongside Spanish and Portuguese, the latter two languages used by $94 \%$ of the population in Latin America (Moreno and Otero, 2016).

This first issue opens with a paper by Teun Van Dijk about concepts needed to approach the relationship between discourse and knowledge. These concepts incorporate the sociocognitive dimension within discourse processing. Here, the concept of common ground knowledge is described as "cultural knowledge," in keeping with later work on the typology of knowledge. This preliminary work was later followed by other publications (such as Van Dijk 2014) that aimed to find a definition for knowledge as consensual belief of epistemic communities and as knowledge attribution in discourse contexts. 


\section{Miguel Farías}

The second article, by Carmen Tisnado, deals with the representations of Spain, starting from the similarities in their titles, in the work of the Peruvian author Iwasaki as his dialogue with Vallejo's canonical text, España aparta de mi este cáliz. The author concludes that even though both voices represent a globalized Spain, the work by Vallejo is engaged in dialogue with other countries beyond Spain, while Iwasaki speaks to and from an internal cultural diversity brought to Spain as a result of globalization.

In the third article, Claudio Araya offers a preview of his doctoral work on the representation of the gay community in two Chilean online newspapers in the context of legislative initiatives such as Civil Unions and homoparental adoptions. The corpus analyzed using Appraisal Theory and operating within the framework of Critical Discourse Studies shows that despite such legislative initiatives, the underlying conservative ideology is supported by heteronormativity that regulates sexuality and affectivity

The fourth article is written in English: Language policies in Brazil and the epistemology underlying the selection of foreign language textbooks, by Gicele Vieira a Kyria Finardi, and is part of a larger project dealing with the teaching of English and internationalization in Brazil. They critically analyze the underlying orientation that governs the selection of foreign language textbooks and their coherence with linguistic policies. In the results, they call for speaking to be included in the textbook evaluation criteria to respond more effectively to the demands for global citizenship.

In the next paper, also in English, Incidental vocabulary acquisition from documentary viewing: A study on the role of captions, Marion Durbahn lays out the results of her study of vocabulary incidental acquisition. A group of Spanish-speaking English language learners was observed under experimental conditions as they watched a scientific video with captions in English. The results, which contribute to the discussion in Applied Linguistics, show that captioning boosted L2 vocabulary and spelling recognition gains.

The sixth paper by Jaime Amaro analyzes Formas de volver a casa by the Chilean author Alejandro Zambra, from the perspective of the poetics of fragments. Said frame, which enables the identification of fragmentation in texts written during and about the Chilean dictatorship, reveals this structure to follow from the expression of factual reality by way of shattered writing.

In the last article included in this issue, Marcos Cárdenas offers us an article on predication in Spanish that deals with the syntactic and semantic dimensions of language. His analysis focuses on secondary predication and on the debate over whether it is a reduced clause or a functional category. His discussion provides projections regarding the neuro linguistic scope of syntactic representations in neural models of language.

This first number of Árboles y Rizomas concludes with two book reviews, one about the last book by the linguist Eugenio Coseriu about schools and trends in semantic studies, written by Carlos Echeverría. The other is a review by Sebastián Reyes of two novels whose themes involve borders and migrations.

Bearing a valuable cargo of writing that arrived in response to our first call to collaborate in this publishing project, we hope that this boat will cruise, safe and sound, into a secure port and at many other ports in the future. 


\section{Miguel Farías}

\section{Incerteza e expectativas ao lançar uma nova revista}

Com uma combinação de prazer, incerteza e muitas expectativas, apresentamos à comunidade acadêmica e às comunidades de leitura especializadas Arboles y Rizomas: Revista de Estudos Lingüísticos e Literários. A revista Árboles y Rizomas oferece um espaço de diálogo acadêmico em torno das investigações na área dos estudos literários e linguísticos, provocando aqueles que tenham a linguagem como centro de suas preocupações, seja em expressões poéticas, seja em sua concretização como língua em uso em discursos e gêneros discursivos diversos. Seu objetivo é estimular, divulgar e contribuir para o desenvolvimento dos estudos literários e linguísticos em suas múltiplas áreas de convergência. Árboles y Rizomas recebe contribuições nos amplos campos dos estudos linguísticos e literários, como por exemplo, em linguiística: a) trabalhos que abordem os diversos níveis da língua: fonológicos, sintáticos, semânticos, pragmáticos, discursivos, ideológicos; b) semiótica; c) língua, sociedade e cultura; d) língua e cognição; e) língua e ideología; f) língua e outros modos semióticos; g) linguística queer; h) etnolingüística; i) língua e educação. Estudos literários: a) teoria literaria; b) literaturas marginalizadas; c) estudos de gêneros (crítica literária feminista, estudos queer, etc.); d) estudos pós-coloniais (subalternidade); e) crítica literária latinoamericana.

O gesto infantil de lançar um barco de papel na água pode emular, com as devidas diferenças, o momento de, finalmente, tornar visível o projeto de publicação que nasceu no Departamento de Lingüística e Literatura da Universidade de Santiago, mas que, como seu nome antecipa, se nutre e se conecta com os apoios (subentendidos e explícitos) de muitos colegas em diferentes paralelos e meridianos neste mundo globalizado e glocalizado.

Satisfação gerada pelos contatos estabelecidos ou renovados e pela possibilidade de oferecer um espaço de diálogo em torno de questões que povoam nossos pensamentos sobre o impacto da globalização, migrações, terrorismo e tecnologias da informação nas preocupações tradicionais das ciências humanas. Além desses, o impacto sobre outros temas contemporáneos, como os problemas de gênero, exílio, tecnoliberalismo, a sobrevivência das comunidades indígenas e outros que desafiam o amplo espectro da língua e literatura. Esperamos que, nas trocas de nossos trabalhos, possamos encontrar referências e reafirmações para enfrentar a incerteza de que as mudanças vertiginosas no cenário sociosemiótico nos ameaçam diariamente. A incerteza também, em um sentido marcado por tensões burocráticas do mundo de publicações acadêmicas que se debatem e, por vezes, naufragam no mar de indexações e outros desafios impostos pelas métricas de produtividade. No entanto, essa incerteza deve se dissipar na busca de otimização de processos editoriais que vamos conhecendo na medida que os editores e autores trabalham juntos para a valorização do conhecimento gerado em nossas comunidades discursivas (Farias, 2018).

As expectativas são animadoras, na medida do possível, favorecer um processo de apoio na divulgação de pesquisas nos vastos campos dos estudos literários e lingüísticos no contexto latino-americano. Temos também expectativas corporativas que esperam uma indexação deste periódico nos registros que midem a produtividade acadêmica.

Em seu título, adotamos "estudos literários e lingüísticos" em vez de literatura e lingüística (que seriam os referentes disciplinares canônicos), a fim de convocar todos aqueles que têm centrado suas preocupações em linguagem, seja em suas expressões poéticas e / ou na sua concretização como linguagem em uso, em discursos e em vários gêneros discursivos. Por outro lado, o conceito de "estudos" abre possibilidades tanto no âmbito semiótico representado pela comunicação humana com a inserção espantosa e vertiginosa de imagens, da leitura digital, 


\section{Miguel Farías}

além da profundidade vasta e extravagante de hyperlinks como a valorização do ensaio como meio de expressão nas ciências humanas (Valdés, 2017).

Vislumbramos um horizonte possível desde que contemos com a generosa colaboração de autores, equipe de apoio e nossos avaliadores. A publicação de um periódico acadêmico que busca padrões de qualidade é um trabalho colosal e é de se esperar que este navio de primeira classe chegue a muitos portos e permita a internacionalização do trabalho acadêmico no campo das ciencias humanas que ocorre na Universidade de Santiago de Chile e, ao mesmo tempo, gere compartilhamento de trabalhos de colegas de outras latitudes. No cotidiano editorial desta revista, um agradecimiento enorme ao constante apoio de Diana Pasmanik e Lorena Garrido, respectivamente Coordenadora Geral e Editora Assistente, sem as quais este trabalho não teria sido possível. Da mesma forma, cabem agradecimentos a todos os avaliadores que enriqueceram com seus comentários os trabalhos publicados.

Tomamos o conceito de árvores e rizomas de Deleuze e Guattari (1987) porque representa metaforicamente as dinâmicas epistemológicas e metodológicas que caracterizam as principais orientações na pesquisa em estudos literários e lingüísticos: atendendo, por um lado, a padrões recorrentes e recursivos que eles nos permitem fazer entradas arbóreas nos textos e discursos e, por outro lado, prestar atenção à polifonia, descontinuidades e vasos comunicantes distantes e descontínuos na comunicação textual humana rizomática. O nome não é apenas uma âncora epistemológica diversificada, mas também se refere à necessidade de fortalecer as redes acadêmicas do Sul com práticas rizomáticas descolonizadoras e colaborativas. Consequentemente, a revista é publicada em três idiomas; inglês, como a língua internacional de comunicação; espanhol e português, como as línguas de comunicação de $94 \%$ dos habitantes da América Latina (Moreno y Otero, 2016).

Esta primeira edição começa com o trabalho de Teun Van Dijk sobre alguns conceitos necessários na abordagem da relação entre discurso e conhecimento que integra a dimensão sociocognitiva no processamento do discurso. Nesta versão do trabalho, o conceito de conhecimento de um denominador comum tem sido chamado de conhecimento cultural, de acordo com os desenvolvimentos posteriores da tipologia do conhecimento. Este é um trabalho pioneiro que mais tarde será refletido em trabalhos (como Van Dijk, 2014) que visam buscar uma definição de conhecimento como crença consensual em comunidades epistêmicas e como alocação de conhecimento em contextos discursivos.

O segundo artigo de Carmen Tisnado trata de, a partir de semelhanças dos títulos, representações de Espanha no trabalho do autor peruano Iwasaki no seu diálogo com o texto canônico de Vallejo Espanha aparta de mim este cálice. A autora conclui que, embora ambas as vozes representam uma Espanha globalizada, a de Vallejo dialoga com outros países fora da Espanha, ao passo que Iwasaki dialoga com a diversidade cultural interna trazida pela globalização.

No terceiro artigo, Claudio Araya nos brinda com uma pista de seu trabalho de doutorado sobre as representações da comunidade gay em dois meios online da imprensa chilena, ou ciberimprensa, a partir da discussão de iniciativas políticas, tais como o Acordo de União Civil e a adoção homoparental. O corpus analisado pela teoria de avaliação e no âmbito de estudos críticos do discurso mostra que, apesar destas iniciativas encontra-se uma ideologia conservadora sustentada por uma hetero normatividade reguladora da sexualidade e do afeto.

No quarto artigo escrito em inglês, Language policies in Brazil and the epistemology underlying the selection of foreign language textbooks, as autoras Gicele Vieira e Kyria Finardi, enriquecendo a sua linha de pesquisa em ensino de inglês e internacionalização, analisam as 


\section{Miguel Farías}

diretrizes para a seleção de textos para o ensino e aprendizagem do inglês e sua relação com as políticas lingüísticas no Brasil. Com base em seus resultados, eles alertam sobre a necessidade de ampliar a perspectiva de ensino do inglês em seu país.

No texto Incidental vocabulary acquisition from documentary viewing: A study on the role of captions, Marion Durbahn mostra o resultado de sua pesquisa sobre a aquisição incidental de vocabulário, para o qual ele observou os efeitos de legendas em inglês de um documentário científico em falantes de espanhol. Em termos de aquisição de vocabulário na segunda língua e a recuperação de formas ortográficas, os resultados apresentam uma contribuição para os estudos em linguística aplicada e, em particular, em relação aos processos envolvidos na aprendizagem de segundas línguas.

No penúltimo artigo apresentado nesta primeira edição, Jaime Amaro discute Maneiras de retornar para casa, do autor chileno Alejandro Zambra, a partir da poética do fragmento, uma teoria que permite recolher a fragmentação das obras escritas na e sobrea ditadura , uma estrutura em consonância com a expressão de uma realidade factual e "escriturística" quebrada.

Finalmente, Marcos Cárdenas nos oferece um artigo sobre predicação que evoca as dimensões sintáticas e semânticas da linguagem. Centra-se na predicação secundária e discute se é uma cláusula mínima ou tem status funcional. A discussão aborda os alcances neurolinguísticos das representações sintáticas em modelos neuronais da linguagem.

Esta primeira edição de Árboles y Rizomas conclui com duas resenhas, uma a respeito do último livro do linguista Eugenio Coseriu sobre as tendências e escolas dos estudos semânticos, escrito por Carlos Echeverria, e outra resenha por Sebastián Reyes sobre dois romances que tratam de questões de fronteira e imigração.

Com esta carga valiosa que inclui as obras que atenderam ao primeiro chamado para colaborar com este projeto editorial, esperamos que este navio chegue a um bom porto e que aporte em muitos outros no futuro.

Miguel Farías, Editor de Árboles y Rizomas

\section{Referencias}

Deleuze, G. \& Guattari, F. (1987). A Thousand Plateaus: Capitalism and Schizophrenia. Minneapolis: University of Minneapolis.

Farías, M. (2018). Algunos desafíos y oportunidades de las revistas especializadas en humanidades en Latinoamérica: redes y trampas. Colombian Applied Linguistics Journal, 20(2), pp. 161-168. https://doi.org/10.14483/22487085.13714

Moreno, F. \& Otero, J. (2016). Atlas de la lengua española en el mundo. Barcelona: Ariel.

Valdés, A. (2017). Redefinir lo humano: Las humanidades en el siglo XXI. Valparaíso: Editorial Universidad de Valparaíso.

Van Dijk, T. (2014). Discourse and Knowledge: A Sociocognitive Approach. Cambridge, U.K.: Cambridge University Press.

Santiago de Chile, Diciembre de 2018 